\title{
PERMENDIKBUD IMPLEMENTATION NO. 3 YEAR 2020 IN THE PREPARATION OF INDONESIAN COURSE LESSON PLAN
}

\author{
Nur Aini Puspitasari*) \\ Universitas Muhammadiyah Prof. Dr. Hamka \\ Andoyo Sastromiharjo \\ Universitas Pendidikan Indonesia \\ *) Correspondences author: Jalan AMD V No. 78 Petukangan Utara, Pesanggrahan, Jakarta Selatan, \\ DKI Jakarta, 12260, Indonesia \\ e-mail: nur.aini.puspitasari@uhamka.ac.id
}

\begin{abstract}
The purpose of this study is to describe the implementation of Permendikbud No. 3 of 2020 in the preparation of the Indonesian Language Course Learning Plan. The method used in this research is descriptive qualitative, the subject studied is the Indonesian Language Course Learning Plan from three universities in Jakarta. The data collection technique in this study is documentation by analyzing the Indonesian Language Course Learning Plan whose preparation is related to Permendikbud No. 3 of 2020. Based on the results of this study, the three universities have implemented Permendikbud No. 3 of 2020, but there are several different terms used, namely learning outcomes into subject learning outcomes, final skills which are expected to be subachievements of course learning, study materials into learning materials.
\end{abstract}

Keywords: Permendikbud No. 3 of 2020, Course Lesson Plan, Indonesian.

\begin{abstract}
Article History: Received: 20/05/2021; Revised: 11/06/2021; Accepted: 15/06/2021; Published: 30/06/2021
How to Cite (MLA 7th): Puspitasari, Nur Aini, Andoyo Sastromiharjo. "Permendikbud Implementation No. 3 Year 2020 in the Preparation of Indonesian Course Lesson Plan." Hortatori Jurnal Pendidikan Bahasa dan Sastra Indonesia 5.1 (2021): 71-78. Print/Online. Copyrights Holder: Nur Aini Puspitasari, Andoyo Sastromiharjo. First Publication: Hortatori Jurnal Pendidikan Bahasa dan Sastra Indonesia (2017).
\end{abstract}

\section{Pendahuluan}

Bahasa Indonesia merupakan bahasa pemersatu bangsa yang digunakan hampir setiap hari oleh warga negara Indonesia. Oleh karena itu, bahasa Indonesia adalah bahasa resmi kenegaraan. Bahkan, bahasa Indonesia dipelajari dari jenjang sekolah dasar sampai perguruan tinggi. Berdasarkan Undangundang No. 12 tahun 2012 pasal 35 tentang kurikulum, pendidikan tinggi wajib memuat mata kuliah Agama, Pancasila, Kewarganegaraan, dan Bahasa Indonesia. Berdasarkan undang-undang tersebut, Bahasa Indonesia menjadi mata kuliah wajib yang harus ada di setiap perguruan tinggi. Mata kuliah Bahasa Indonesia sebagai mata kuliah wajib umum (MKWU) merupakan mata kuliah strategis yang dapat mentransmisi dan mentranformasi sikap serta perilaku mahasiswa Indonesia.

Tujuan mata kuliah wajib umum di perguruan tinggi menjadi sumber nilai, pedoman dan pengembangan program studi. Tak beda dengan Bahasa Indonesia sebagai MKWU mengantarkan mahasiswa dalam memantapkan kepribadian secara konsisten dalam mewujudkan rasa kebangsaan dan cinta tanah air sepanjang hayat (Kementerian Riset). Pada umumnya capaian pembelajaran mata kuliah Bahasa Indonesia di setiap perguruan tinggi agar mahasiswa mampu mengembangkan literasi akademik dalam bentuk penulisan karya ilmiah dengan sistematika dan bahasa yang baik dan benar.

Dalam mewujudkan tujuan mata kuliah wajib umum Bahasa Indonesia maka perlu disusun rencana pembelajaran yang sejalan dengan arah dan tujuan kualifikasi kerangka nasional Indonesia (KKNI). 
Rencana pembelajaran semester (RPS) merupakan aktivitas yang akan dilakukan dosen kepada mahasiswa dalam proses pembelajaran/ perkuliahan (Nurdin). Rencana pembelajaran semester (RPS) juga memiliki definisi sebagai rencana proses pembelajaran yang disusun untuk kegiatan pembelajaran selama satu semester untuk memenuhi capaian pembelajaran lulusan yang dibebankan pada mata kuliah (Junaidi). Oleh karena itu, rencana pembelajaran semester (RPS) merupakan hal yang tidak dapat dipisahkan dengan pembelajaran. Bahkan sebelum dosen memberikan pembelajaran di kelas hal pertama yang harus dilakukan adalah menyusun rencana pembelajaran semester (RPS).

Permasalahan yang sering kali terjadi adalah dosen menyusun RPS tanpa memerhatikan dan mengidentifikasi komponen dan isi yang terdapat dalam RPS. Selain itu, tanpa mempertimbangkan capaian pembelajaran yang diharapkan. Padahal manfaat dalam penyusunan RPS adalah kegiatan belajar mengajar lebih terarah, mudah mengevaluasi hasil belajar yang telah disampaikan, dan dosen dapat mengajar sesuai kurikulum yang berlaku (Sudiarta). Kurikulum yang berlaku dalam pendidikan tinggi adalah Pendidikan berbasis capaian (outcome-based education) dan kurikulum berbasis capaian (outcome-based curriculum) atau kurikulum berbasis kompetensi (competency-based curriculum) (Suwandi).

Perancangan pembelajaran perlu dilakukan secara sistematis, logis, dan terstruktur agar menghasilkan rencana pembelajaran semester (RPS). Rencana pembelajaran yang sistematis, logis, dan terstruktur dapat menjamin tercapainya capaian pembelajaran lulusan (CPL). Oleh karena itu, setidaknya dalam perancangan pembelajaran dapat melalui tahapan sebagai berikut, (a) mengidentifikasi CPL yang dibebankan pada mata kuliah, (b) merumuskan capaian pembelajaran mata kuliah (CPMK) berdasarkan CPL yang mengacu pada mata kuliah tersebut, (c) merumuskan sub-CPMK berdasarkan rumusan CPMK sebagai kemampuan akhir yang direncanakan pada tiap tahap pembelajaran, (d) menganalisis pembelajaran sebagai tahapan pembelajaran yang akan dijalani, (e) menganalisis kebutuhan belajar untuk mengetahui kebutuhan lulusan, kedalaman materi, dan perangkat pembelajaran yang diperlukan, (f) menentukan indikator pencapaian sub-CPMK untuk memenuhi CPL sebagai kemampuan akhir yang direncanakan, $(\mathrm{g})$ menetapkan kriteria penilaian dan mengembangkan instrumen penilaian berdasarkan indikator pencapaian sub-CPMK, (h) sebagai pengalaman belajar maka perlu dipilih dan dikembangkan bentuk bahan ajar, metode pembelajaran, dan penugasan mahasiswa, (i) mengembangkan materi pembelajaran dan sumber belajar yang sesuai dalam bentuk bahan ajar, (j) mengembangkan dan mengevaluasi pembelajaran yang bersifat formatif dan sumatif (Junaidi). Perancangan pembelajaran sebaiknya dapat diukur kelesuannya dengan SN-Dikti.

Rumusan sikap dan keterampilan umum berdasarkan Permendikbud No. 3 tahun 2020 pasal 7 ayat (1) sebagai bagian dari capaian pembelajaran lulusan untuk setiap program dan jenis pendidikan tinggi tidak terpisahkan dari peraturan menteri ini. Definisi sikap dan keterampilan umum berdasarkan Permendikbud No. 3 Tahun 2020 sebagai berikut sikap merupakan perilaku benar dan berbudaya sebagai hasil dari internalisasi dan aktualisasi nilai dan norma yang tercermin dalam kehidupan spiritual dan sosial melalui proses pembelajaran, pengalaman kerja mahasiswa, penelitian dan/ atau pengabdian kepada masyarakat yang terkait pembelajaran. Sedangkan keterampilan umum sebagai kemampuan kerja umum yang wajib dimiliki oleh setiap lulusan dalam rangka menjamin kesetaraan kemampuan lulusan sesuai tingkat program dan jenis pendidikan tinggi. Dalam penelitian ini hanya menganalisis rumusan capaian sikap dan keterampilan umum yang digunakan pada perguruan tinggi yang dikaji. Untuk pengetahuan dan keterampilan khusus dirumuskan berdasarkan forum program studi sejenis atau asosiasi atau pengelola program studi yang tidak memiliki forum program studi sejenis.

Rencana pembelajaran semester memiliki manfaat bagi dosen yaitu (a) merancang perkuliahan secara holistik dan sistematis, (b) menyusun SAP, (c) mengevaluasi dan meningkatkan mutu kegiatan perkuliahan yang sedang berlangsung, (d) merancang perkuliahan semester berikutnya. Sedangkan manfaat RPS bagi mahasiswa memberikan informasi tentang (a) mata kuliah secara utuh, (b) beban tugas dan tagihan mata kuliah, (c) gaya belajar yang sesuai, dan (d) sistem penilaian hasil belajar (Sitepu).

Dalam KKNI rencana pembelajaran semester tertuang dalam Permenristekdikti No. 44 Tahun 2015 pasal 10 ayat (2). Dijelaskan pada ayat (1) bahwa rencana pembelajaran semester (RPS) ditetapkan dan dikembangkan oleh dosen secara mandiri atau berkelompok keahlian suatu bidang ilmu pengetahuan dan/atau teknologi dalam program studi.

Seiring dengan pengembangan pendidikan Menteri Pendidikan dan Kebudayaan menerbitkan Peraturan Menteri Pendidikan dan Kebudayaan Republik Indonesia Nomor 3 Tahun 2020 tentang Standar Nasional Pendidikan Tinggi. Pada pasal 12 ayat (3) rencana pembelajaran semester atau istilah lain paling sedikit memuat: (a) nama program studi, nama dan kode mata kuliah, semester, sks, nama dosen pengampu; 
(b) capaian pembelajaran lulusan yang dibebankan pada mata kuliah; (c) kemampuan akhir yang direncanakan pada tiap tahap pembelajaran untuk memenuhi capaian pembelajaran lulusan; (d) bahan kajian yang terkait dengan kemampuan yang ingin dicapai; (e) metode pembelajaran; (f) waktu yang disediakan untuk mencapai kemampuan pada tiap tahap pembelajaran; $(\mathrm{g})$ pengalaman belajar mahasiswa yang diwujudkan dalam deskripsi tugas yang harus dikerjakan oleh mahasiswa selama satu semester; (h) kriteria, indikator, dan bobot penilaian; dan (i) daftar referensi yang digunakan.

Pada umumnya hasil penelitian tentang penyusunan RPS membahas tentang validitas Rencana Pembelajaran Semester yang mencakup aspek format RPS, isi, bahasa dan tulisan, serta manfaat RPS, persentase dosen membuat RPS, keterlibatan mahasiswa dalam menyempurnakan RPS, kebermanfaatan RPS bagi mahasiswa, pengetahuan mahasiswa terhadap pokok bahasan dan tujuan pembelajaran, serta rujukan yang digunakan, pengisian RPS sesuai dengan aplikasi berbasis online, perangkat pembelajaran yang memuat CPL, CPMK, dan Sub-CPMK, pengembangan rencana pembelajaran di perguruan tinggi dalam membuat e-materi (Afrahamiryano, 2018; Sitepu, 2018; Syafarina \& Setiawan, 2019; Hartini \& SS, 2019; Schreglmann \& Kazanci, 2018).

Berbeda dengan penelitian yang sudah dilakukan, maka peneliti tertarik untuk mengkaji Implementasi Peremendikbud No. 3 Tahun 2020 dalam penyusunan RPS Bahasa Indonesia. Dalam penelitian ini fokus yang peneliti lakukan adalah komponen penyusunan RPS yang sesuai dengan Permendikbud No. 3 Tahun 2020 dan rumusan capaian pembelajaran sikap dan keterampilan umum yang yang digunakan dalam penyusnan RPS Bahasa Indonesia. Rumusan masalah dalam penelitian ini adalah bagaimanakan impelementasi Permendikbud No. 3 Tahun 2020 dalam penyusunan RPS Bahasa Indonesia?

\section{Metode}

Penelitian ini menggunakan pendekatan deskriptif kualitatif. Deskriptif kualitatif merupakan penelitian yang menyajikan fakta secara apa adanya (Nuryani). Penelitian ini juga memaparkan secara mendalam implementasi Permendikbud No. 3 Tahun 2020 dalam penyusunan RPS Bahasa Indonesia. Sumber data dalam penelitian ini adalah RPS Bahasa Indonesia yang terdapat pada tiga perguruan tinggi di Jakarta. Data yang dianalisis dalam penelitian adalah komponen penyusunan RPS yang terdapat dalam Permendikbud No. 3 Tahun 2020 dan rumusan capaian pembelajaran sikap dan keterampilan umum yang digunakan dalam penyusunan RPS Bahasa Indonesia.

Teknik pengumpulan data dalam penelitian ini adalah dokumentasi. Peneliti menggunakan reduksi data, display data, dan penarikan simpulan. Reduksi data peneliti mengumpulkan dokumen RPS Bahasa Indonesia dari rekan yang mengajar Bahasa Indonesia pada tiga perguruan tinggi di Jakarta. Display data digunakan untuk menyajikan data secara deskriptif, yaitu menganalisis ketiga RPS Bahasa Indonesia berdasarkan komponen yang terdapat dalam Permendikbud No. 3 tahun 2020 dan mendeskripsikan komponen yang terdapat dalam tiga RPS Bahasa Indonesia yang dianalisis. Penarikan simpulan dan penguatan keputusan akhir.

\section{Hasil dan Diskusi}

Berdasarkan Permendikbud No. 3 Tahun 2020 Pasal 12 ayat (3), komponen penyusunan RPS meliputi identitas RPS, capaian pembelajaran, kemampuan akhir yang diharapkan, bahan kajian, metode pembelajaran, waktu yang disediakan, pengalaman belajar, kriteria, indikator, penilaian, dan daftar referensi. Hasil temuan pada tiga universitas yang diteliti terdapat satu universitas yang capaian pembelajaran mata kuliah bukan capaian pembelajaran lulusan yang sudah ditetapkan dalam Permendikbud NO. 3 Tahun 2020, satu universitas tidak menggunakan istilah kemampuan akhir yang diharapkan, tetapi menggunakan istilah sub-CPMK, dan dua universitas menggunakan istilah yang berbeda dalam penggunaan istilah bahan kajian, 
Tabel 1 Hasil Temuan Komponen Penyusunan RPS Bahasa Indonesia

\begin{tabular}{|c|c|c|c|c|c|c|c|c|c|c|}
\hline \multirow[t]{2}{*}{ No } & \multirow[t]{2}{*}{ Nama Universitas } & \multicolumn{9}{|c|}{ Komponen } \\
\hline & &  & 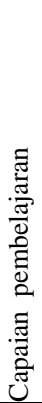 & 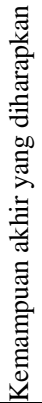 &  & 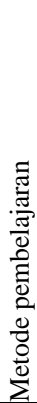 & 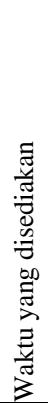 & 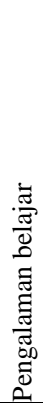 & 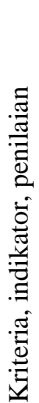 & 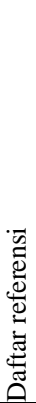 \\
\hline 1 & A & $\mathrm{V}$ & $\mathrm{V}$ & $\mathrm{V}$ & & V & $\mathrm{V}$ & V & V & V \\
\hline 2 & B & V & V & & $\mathrm{V}$ & V & $\mathrm{V}$ & $\mathrm{V}$ & V & V \\
\hline 3 & $\mathrm{C}$ & $\mathrm{V}$ & & $\mathrm{V}$ & $\mathrm{V}$ & $\mathrm{V}$ & $\mathrm{V}$ & $\mathrm{V}$ & $\mathrm{V}$ & $\mathrm{V}$ \\
\hline
\end{tabular}

Pembahasan dalam penelitian ini meliputi komponen penyusunan RPS dalam Permendikbud No. 3 Tahun 2020.

\section{Identitas RPS}

Identitas RPS Bahasa Indonesia mencakup nama program studi, nama dan kode mata kuliah, semester, sks, dan nama dosen pengampu. Identitas RPS Bahasa Indonesia pada Universitas A, B, dan C mengacu pada Permendibud No. 3 Tahun 2020. Dari ketiga universitas menambahkan komponen tanggal pembuatan/ terbitnya RPS. Universitas A dan B mencantumkan koordinator mata kuliah Bahasa Indonesia dan ketua program studi/ jurusan dan tanggal penyusunan yang dikembangkan oleh universitas. Dapat disimpulkan pada Universitas A, B, dan C sudah mengimplementasikan Permendikbud No. 3 Tahun 2020 karena sudah memenuhi pada komponen identitas RPS.

2. Capaian pembelajaran

Cakupan pembelajaran merupakan rumusan capaian akhir pembelajaran yang mencakup unsur sikap, pengetahuan, keterampilan umum, dan keterampilan khusus. Universitas A dan B menuliskan capaian pembelajaran yang mengandung unsur sikap, pengetahuan, keterampilan umum, dan keterampilan khusus secara jelas. Hal ini sudah sesuai dengan Permendikbud No. 3 Tahun 2020 pasal 7.

Pada universitas $\mathrm{C}$ capaian pembelajaran mencantumkan capaian pembelajaran lulusan yang belum sesuai dengan Permendikbud No. 3 Tahun 2020 pasal 7 ayat (1) dan (2) karena hanya mencantumkan capaian pembelajaran mata kuliah di dalamnya. Jadi pada Universitas C CPL yang dicantumkan pada RPS Bahasa Indonesia belum mencantumkan rumusan capaian sikap dan keterampilan umum.

Rumusan capaian pembelajaran sikap yang diimplementasikan pada Universitas A terdiri atas 5 rumusan capaian sikap yang mencakup S2, S3, S4, S10, dan S11. Pada rumusan S11 ditambahkan sesuai dengan visi universitas tersebut. Sedangkan pada Universitas B rumusan capaian pembelajaran sikap terdiri atas 6 rumusan CP sikap yang mencakup S1, S2, S3, S4, S6, dan S9. Rumusan capaian pembelajaran sikap yang diimplementasikan pada Universitas A dan B sebagai berikut.

a. Rumusan S1 (Sikap ke-1) berbunyi Bertakwa kepada Tuhan Yang Maha Esa dan mampu menunjukkan sikap religius. Implementasi rumusan S1 ini hanya digunakan oleh Universitas B yang berlatar belakang sebagai kampus islami. Oleh karena itu, dalam capaian pembelajarannya menunjukkan sikap religius.

b. Rumusan S2 (Sikap ke-2), berbunyi menjunjung tinggi nilai kemanusiaan dalam menjalankan tugas berdasarkan agama, moral, dan etika. Universitas A dan B mengimplementasikan S2. Kedua universitas tersebut mengimplementasikan nilai kemanusiaan yang mengarah pada agama, moral, dan etika mahasiswa sebagai capaian pembelajaran lulusan. Hal ini diharapkan agar mahasiswa dalam mengerjakan tugas dapat bertoleransi dengan rekannya.

c. Rumusan S3 (Sikap ke-3) berbunyi berkontribusi dalam peningkatan mutu kehidupan bermasyarakat, berbangsa, bernegara, dan kemajuan peradaban berdasarkan Pancasila. Universitas A dan B mengimplementasikan S3 sebagai capaian pembelajaran lulusan yang dapat mengimplementasikan nilai Pancasila untuk peningkatan mutu dalam kehidupan mahasiswa yang dapat dintegrasikan pada mata kuliah Bahasa Indonesia. Hal ini mengarah pokok bahasan tentang 
sejarah, kedudukan, dan fungsi bahasa Indonesia yang tercantum dalam Pancasila sila ke-3 untuk mewujudkan bela negara dan nasionalisme. Selain itu, pada penerapan kaidah Pedoman Umum Ejaan Bahasa Indonesia (PUEBI) sebagai upaya penanaman rasa nasionalisme pada mahasiswa.

d. Rumusan S4 (Sikap ke-4) berbunyi berperan sebagai warga negara yang bangga dan cinta tanah air, memiliki nasionalisme serta rasa tanggungjawab pada negara dan bangsa. Universitas A dan B mengimplementasikan S4 sebagai capaian lulusan pada mata kuliah Bahasa Indonesia karena mahasiswa harus berbangga dan cinta tanah air sebagai wujud penggunaan bahasa Indonesia yang baik dan benar. Selain itu, mahasiswa akan memiliki rasa tanggung jawab pada negara dan bangsanya melalui penggunaan bahasa Indonesia di ruang publik dan mengimplementasikan kaidah bahasa Indonesia dalam bentuk tugas akhirnya.

e. Rumusan S6 (Sikap ke-6) berbunyi bekerja sama dan memiliki kepekaan sosial serta kepedulian terhadap masyarakat dan lingkungan. Rumusan S6 ini diimplementasikan oleh Universitas B. Hal ini dipilih karena capaian pembelajaran lulusan ini mengacu pada visi universitas tersebut yang mengutamakan kecerdasan sosial. Selain itu, pada pokok mata kuliah bahasan Indonesia yang tertuang dalam RPS-nya, mahasiswa mampu menulis karangan ilmiah berdasarkan observasi lapangan sehingga membutuhkan kerja sama dan kepekaan sosial di dalamnya terhadap orang-orang yang dijadikan informan atau responden.

f. Rumusan S9 (Sikap ke-9) berbunyi menunjukkan sikap bertanggungjawab atas pekerjaan di bidang keahliannya secara mandiri. Universitas B ini mengimplementasikan rumusan S9 sebagai wujud CPL yang bertanggung jawab dalam mengerjakan tugas-tugasnya sesuai dengan bidang keahlian.

g. Rumusan S10 (Sikap ke-10) berbunyi menginternalisasi semangat kemandirian, kejuangan, dan kewirausahaan. Universitas A mengimplementasikan S10 karena disesuaikan dengan CPL yang ditetapkan oleh perguruan tingginya yang mengacu pada semangat kewirausahaan mahasiswa.

Rumusan capaian pembelajaran sikap pada kedua universitas memiliki kesamaan pada rumusan capaian pembelajaran S2, S3, dan S4. Sedangkan pada Universitas C belum mencantumkan rumusan capaian pembelajaran sikap pada RPS Bahasa Indonesia.

Rumusan CP keterampilan umum pada Universitas diimplementasikan 3 keterampilan umum yang mencakup KU1, KU4, dan KU8. Sedangkan pada Universitas B CP keterampilan umum terdiri atas 4 keterampilan umum yang mencakup KU1, KU4, KU5, dan KU8. Rumusan capaian pembelajaran keterampilan umum pada Universitas A dan B sebagai berikut.

a. Rumusan KU1 (keterampilan umum ke-1) berbunyi mampu menerapkan pemikiran logis, kritis, sistematis, dan inovatif dalam konteks pengembangan atau implementasi ilmu pengetahuan dan teknologi yang memperhatikan dan menerapkan nilai humaniora yang sesuai dengan bidang keahliannya. Universitas A dan B mengimplementasikan KU1 sebagai capaian pembelajaran merupakan bentuk luaran mata kuliah Bahasa Indonesia adalah karya tulis ilmiah maka mahasiswa harus mampu menerapkan pemikiran logis, kritis, sistematis, dan inovatif dalam keilmuannya.

b. Rumusan KU4 (keterampilan umum ke-4) berbunyi mampu menyusun deskripsi saintifik hasil kajian tersebut di atas dalam bentuk skripsi atau laporan tugas akhir, dan mengunggahnya dalam laman perguruan tinggi. Universitas A dan B mengimplementasikan KU4 sebagai capaian pembelajaran karena melalui mata kuliah Bahasa Indonesia menjadi landasan untuk menyusun skripsi. Hal ini terkait dengan mengaplikasikan kaidah kebahasaan yang mencakup ejaan, kalimat efektif, paragraf yang efektif, penulisan kutipan yang tepat, dan tugas akhir yang berbentuk laporan ilmiah atau karya tulis ilmiah.

c. Rumusan KU5 (keterampilan umum ke-5) berbunyi mampu mengambil keputusan secara tepat dalam konteks penyelesaian masalah di bidang keahliannya, berdasarkan hasil analisis informasi dan data. Rumusan KU5 hanya diimplementasikan oleh Universitas B. Hal ini karena luaran pada mata kuliah Bahasa Indonesia adalah laporan karya ilmiah atau karya ilmiah. Oleh karena itu, perlu dalam pengambilan keputusan dalam penyelesaian masalah sesuai dengan bidang keilmuan yang akan diaplikasikan dalam karya tulis ilmiah.

d. Rumusan KU8 (keterampilan umum ke-8) berbunyi mampu melakukan proses evaluasi diri terhadap kelompok kerja yang berada dibawah tanggung jawabnya, dan mampu mengelola pembelajaran secara mandiri. Rumusan KU8 ini diimplementasikan oleh Universitas A dan B. Tugas pada mata kuliah Bahasa Indonesia di kedua perguruan tinggi tersebut dilakukan secara berkelompok. Oleh karena itu, masing-masing mahasiswa dapat melakukan belajar mandiri yang nantinya dikembangkan dalam kelompok diskusi. 
Terdapat kesamaan rumusan capaian keterampilan umum yang digunakan oleh Universitas A dan B yang terletak pada KU4 dan KU8. Berbeda pada Universitas C rumusan capaian keterampilan umum tidak tercantum dalam RPS Bahasa Indonesia.

Pada capaian pembelajaran lulusan (CPL) dua universitas, yaitu Universitas A dan B sudah mengimplementasikan Permendikbud No. 3 Tahun 2020 karena kesesuaiannya dengan SN-Dikti. Sedangkan Universitas C belum mencantumkan CPL yang sesuai dengan Permendikbud No. 3 Tahun 2020.

3. Kemampuan akhir yang diharapkan

Pada komponen ini kemampuan tiap tahap pembelajaran yang diharapkan mampu berkontribusi pada pemenuhan CPL. Kemampuan akhir yang di akhir atau sub-CPMK. Universitas A dan C menggunakan istilah kemampuan akhir yang diharapkan sedangkan Universitas B menggunakan istilah sub-CPMK. Pada ketiga universitas tersebut kemampuan akhir yang diharapkan sama yang dimulai dengan mahasiswa menjelaskan sejarah, kedudukan, dan fungsi bahasa Indonesia, mengimplementasikan ejaan, mengimplementasikan kalimat, mengimplementasikan paragraf, mengaplikasikan konvensi naskah, membuat karya tulis ilmiah. Hanya saja pada Universitas A dalam menuliskan kemampuan akhir yang diharapkan lebih terinci dengan menambahkan unsur nasionalisme dan pajak.

4. Bahan kajian

Bahan kajian berisi pengetahuan dari disiplin ilmu tertentu atau pengetahuan yang dapat dipelajari oleh mahasiswa (Anderson and Kratwohl). Istilah bahan kajian diimplementasikan oleh Universitas A sedangkan Universitas B dan C menggunakan istilah materi pembelajaran. Bahan kajian dan materi pembelajaran sebenarnya sama sebagai penciri program studi. Selain itu, bahan kajian terkait dengan kemampuan yang akan dicapai oleh mahasiswa pada pembelajaran yang ditempuhnya. Jadi Universitas B dan C sudah mengimplementasikan Permendikbud No. 3 Tahun 2020.

5. Metode pembelajaran

Komponen ini merupakan langkah atau cara yang digunakan untuk merealisasikan strategi pembelajaran dengan menggunakan strategi dan media pembelajaran (Joice). Metode dalam RPS metode yang dapat memfasilitasi capaian pembelajaran, misalnya pembelajaran kolaboratif, pembelajaran kooperatif, simulasi, berbasis proyek, dan sebagainya.

Metode pembelajaran yang digunakan dalam penyusun RPS Bahasa Indonesia pada Universitas A sudah mengimplementasikan kuliah, pembelajaran kolaboratif, kooperatif, simulasi, dan proyek yang sesuai dengan Permendikbud No. 3 Tahun 2020. Berbeda pada Universitas B metode pembelajaran yang digunakan hanya kuliah, diskusi dan simulasi. Universitas $\mathrm{C}$ metode pembelajaran yang digunakan adalah kuliah, diskusi, simulasi dan pembelajaran kooperatif. Pada Permendikbud No. 3 Tahun 2020 pasal 14 ayat (3), metode pembelajaran yang dimaksud adalah diskusi kelompok, simulasi, studi kasus, pembelajaran kolaboratif, pembelajaran kooperatif, pembelajaran berbasis proyek, pembelajaran berbasis masalah, atau pembelajaran lainnya. Berdasarkan Pasal 14 ayat (2) Proses Pembelajaran melalui kegiatan kurikuler wajib menggunakan metode pembelajaran yang efektif sesuai dengan karakteristik mata kuliah untuk mencapai kemampuan tertentu yang ditetapkan dalam mata kuliah dalam rangkaian pemenuhan capaian pembelajaran lulusan.

Mata kuliah Bahasa Indonesia di tingkat perguruan tinggi tidak hanya pada ranah kognitif saja, tetapi mahasiswa mampu menciptakan sesuatu dalam bentuk karya tulis ilmiah. Untuk itu, pada Universitas B dan C perlu dikembangkan kembali metode pembelajaran yang sesuai dengan Permendikbud No. 3 Tahun 2020.

6. Waktu yang disediakan

Waktu yang diberikan dalam RPS harus sesuai dengan beban belajar mahasiswa dan menunjukkan kapan pelaksanaan pembelajaran dilakukan. Waktu yang disediakan dalam satu semester adalah minggu ke-1 sampai ke-16 dan mencakup kemampuan mahasiswa. Waktu yang diimplementasikan dalam RPS Bahasa Indonesia dari ketiga universitas tersebut sudah mengimplementasikan Permendikbud No. 3 Tahun 2020 karena waktu yang disediakan sudah sesuai dengan jumlah SKS. Selain itu, pada waktu pembelajaran juga sudah dipaparkan hitungan tatap muka, belajar terstruktur, dan belajar mandiri yang dideskripsikan berdasarkan hitungan SKS. 
7. Pengalaman belajar

Pengalaman belajar merupakan aktivitas belajar dalam trasfigurasi materi pembelajaran menjadi pengetahuan bermakna (Ornstein dan Hunskins). Dalam RPS Bahasa Indonesia bentuk pengalaman belajar dapat diwujudkan dengan deskripsi tugas yang dikerjakan selama satu semester dan pengalaman belajar juga mampu mencapai kemampuan yang diharapkan. Pengalaman belajar pada Universitas A dan C sudah mengimplementasikan Permendikbud No. 3 Tahun 2020 karena sudah mendeskripsikan tugas yang dikerjakan selama satu semester. Sedangkan pada Universitas B pengalaman belajar tercantum dalam RPS Bahasa Indonesia.

8. Kriteria, indikator, penilaian

Kriteria penilaian sebagai patokan untuk mengukur ketercapaian pembelajaran berdasarkan indikator yang telah ditetapkan (Brookhart). Kriteria dalam RPS mengacu pada standar keberhasilan mahasiswa dalam sebuah pembelajaran.

Indikator dalam RPS adalah pencapaian yang terukur dalam pembelajaran. Indikator juga merupakan hal yang menunjukkan kinerja mahasiswa.

Penilaian merupakan capain hasil belajar atau kinerja mahasiswa yang dapat diukur. Dalam RPS penilaian berbentuk persentase keberhasilan belajar mahasiswa terhadap keberhasilan keseluruhan mata kuliah.

Pada ketiga universitas tersebut sudah mengimplementasikan kriteria, indikator, dan penilaian dalam RPS Bahasa Indonesia yang disusun. Hal ini sudah sesuai dengan Permendikbud No. 3 Tahun 2020. Kriteria penilaian yang tertulis dalam RPS Bahasa Indonesia dan indikator dapat terukur. Karena kriteria penilaian dan indikator sudah terintegrasi dengan kemampuan akhir yang diharapkan atau subCPMK.

9. Daftar referensi

Sumber belajar yang diberikan kepada mahasiswa berupa buku atau bentuk lain yang didapat dijadikan acuan dalam pembelajaran. (Kementerian Riset). Ketiga universitas tersebut sudah mengimplementasikan daftar referensi yang tercantum dalam setiap pertemuan dan dilengkapi dengan halaman. Bahkan daftar referensi yang digunakan juga tidak hanya bersumber dari buku melainkan hasil penelitian dan pengabdian dosen. Hal ini sudah sesuai dengan Permendikbud No. 3 Tahun 2020.

\section{Simpulan}

Berdasarkan hasil penelitian maka dapat disimpulkan bahwa Universitas A, B, dan C sudah mengimplementasikan Permendikbud No. 3 Tahun 2020 pasal 12 ayat (3) dalam komponen penyusunan RPS Bahasa Indonesia. Hal ini dinyatakan dengan kesesuaian komponen yang terdapat pada pasal 12 ayat (3). Universitas B dan C menggunakan istilah lain untuk bahan kajian, yaitu materi pembelajaran yang pada dasarnya sama. Selain itu, metode pembelajaran di Universitas B dan C perlu dikembangkan sesuai Permendikbud No. 3 Tahun 2020 pasal 14 ayat (3).

\section{Ucapan Terima Kasih}

Penulis mengucapkan terima kasih kepada semua pihak yang terlibat dalam penyusunan artikel ini.

\section{Daftar Rujukan}

Afrahamiryano. "Validitas Rencana Pembelajaran Semester Mata Kuliah Kimia Dasar Program Studi Pendidikan Biologi Universitas Mahaputra Muhammad Yamin." Jurnal Eksakta Pendidikan (JEP) 2.1 (2018): 49-55.

Anderson, Lorin W and David R. Kratwohl. A Taxonomy for Learning, Teaching and Assesing: A Revision of Blooms Taxonomy of Educational Objective. New York: Longman, 2001.

Brookhart, Susan M., and Anthony J. Nitko. Educational Assesment of Student (7Ed). New Jersey: Pearson, 2015.

Hartini, Sri and Hera Heru SS. "Analisis Sinkronitas Rencana Pembelajaran Semester (RPS) dengan Rencana Tugas Semester Mahasiswa (RTM) dan Rencana Evaluasi Pembelajaran (REP) Dosen FKIP UNISRI Tahun 2018." Research Fair Unisri 3.1 (2019): 608-621.

Joyce, Bruce, Marsha Weil, and Emily Calhoun. Models of Teaching ( 8 ed). New Jersey: Pearson Education, Inc., 2009. 
Junaidi, Aris. Panduan Penyusunan Kurikulum Pendidikan Tinggi di Era Industri 4.0 untuk Mendukung Merdeka Belajar-Kampus Merdeka. Jakarta: Direktorat Jenderal Pendidikan Tinggi Kementerian Pendidikan dan Kebudayaan RI, 2020.

Kementerian Riset, Teknologi dan Pendidikan Tinggi Republik Indonesia. Bahasa Indonesia untuk Perguruan Tinggi. Jakarta: Direktorat Jenderal Pembelajaran dan Kemahasiswaan Kementerian Riset Teknologi dan Pendidikan Tinggi, 2016.

Nurdin, Starifuddin. "Pengembangan Kurikulum dan Rencana Pembelajaran Semester (RPS) Berbasis KKNI di Perguruan Tinggi." Jurnal Manajemen Pendidikan: Al Fitrah 5.1 (2017): 21-30. <http://ecampus.iainbatusangkar.ac.id/ojs/index.php/alfikrah/article/view/813/760>.

Nuryani. "Peran MKWU Bahasa Indonesia sebagai Penguat Identitas dan Nasionalisme Mahasiswa PTKI (Studi Pelaksana MKWU Bahasa Indonesia di UIN Syarif Hidayatullah)." Kembara: Jurnal Keilmuan Bahasa, Sastra, dan Pengajarannya $5.2 \quad$ (2019): 231-244. <http://ejournal.umm.ac.id/index.php/kembara/article/view/8370>.

Ornstein, Allan C. and Francis P. Hunkins. Curriculum: Faoundations, Principles, and Issue (4 ed). New York: Pearson, 2004.

Schreglmann, Sinan and Zekeriya Kazanci. "A Lesson PLan Development Study for Higher Education Based on Needs Assessment "Graphics and Animation in Education" Course." International Education Studies 11.7 (2018): 155-165.

Sitepu, Bintang Petrus. "Pelaksanaan Rencana Pembelajaran Semester dalam Proses Pembelajaran di Perguruan Tinggi." Perspektif Ilmu Pendidikan, Jurnal Universitas 32.1 (2018): 43-51. <http://journal.unj.ac.id/unj/index.php/pip/article/view/6697>.

Sudiarta, I Nengah. "Upaya Penggunaan Rencana Pembelajaran Semester Dalam Menunjang Proses Belajar Mengajar di FKIP Universitas Dwijendra Depansar." Jurnal Kajian Pendidikan Widya Accarya FKIP Universitas Dwijendra 5.1 (2016): 30-39.

Suwandi, Sarwiji. "Pengembangan Kurikulum Program Studi Pendidikan Bahasa (dan Sastra) Indonesia yang Responsif terhadap Kebijakan Merdeka Belajar-Kampus Merdeka dan Kebutuhan Pembelajaran Abad ke-21." Seminar Daring Nasional: Pengembangan Kurikulum Merdeka Belajar. Bengkulu: Jurusan Pendidikan Bahasa dan Seni, Universitas Bengkulu, 2020. 1-12.

Syafarina, Gita Ayu and Agus Setiawan. "Perancangan Aplikasi Rencana Pembelajaran Semester (RPS) untuk Meningkatkan Pencapaian Pembelajaran bagi Dosen." Technologia 10.4 (2019): 202-207. 